\title{
Identifying Students' Learning Styles and Its Implications for Educators in The EFL Classroom
}

\author{
Lizzani Kurnia Pratiwi* \\ English Language Education Department \\ Universitas Negeri Yogyakarta \\ Yogyakarta, Indonesia \\ pratiwilizzani@gmail.com
}

\author{
Anita Triastuti \\ English Language Education Department \\ Universitas Negeri Yogyakarta \\ Yogyakarta, Indonesia \\ anitatria@uny.ac.id
}

\begin{abstract}
This paper concerns the individual differences between English as a Foreign Language (EFL) learners. Related to the specific area in individual differences research, this article attempts to identify students' learning styles in the EFL classroom. Respondents were 20 first-semester graduates majoring in English language education at Yogyakarta state university. They responded to the Learning Style Survey developed by Cohen, Oxford, and Chi (2001). The researcher collected and analyzed the data descriptively. The study revealed that in sensory preferences, visual learning style has the highest frequency among male and female students, while random-intuitive is the most preferred learning style regarding personality types, and synthesizing is overflowing in cognitive styles. Finally, the author discussed the teaching strategies based on students' preferred learning styles for Educators in the EFL Classroom to enhance the teaching and learning process.
\end{abstract}

Keywords - individual differences, learning styles, EFL learners

\section{INTRODUCTION}

In every human being, a person already had his/her characteristic; this kind of personality makes he/she differs from each other. Some experts define those things as individual differences (Ellis, 1989; Skehan, 1991; Ortega, 2013). Those differences have their impact on education, which is they will learn something in a different way and will affect how well they will gain knowledge.

Two factors affected the learning achievement, which are the external factors and internal factors (Lightbown et al., 1999). External factors refer to those that characterize the particular language learning situation such as curriculum, instruction, access to the native speaker, culture, and status while internal factors are those that the learner brings to the learning situation such as language aptitude, personality, learning styles, motivation, learning strategies, and multiintelligence.

Indeed, in Indonesia, many efforts had been made by the government to improve the quality of EFL teaching from the external factors, including the curriculum changes and the use of innovative instructions to assess the students' learning skills. However, those efforts were still not enough to improve the quality of students' learning. Many people criticized that EFL teaching at school failed to develop the learners' English communicative skills (Madya, 2002; Widayanti, 2013). Regarding this, we should take the internal factor into account, which is the learning style.
Learning style is one of the factors that can influence any students' ability to learn in a particular instructional context since it affected each student's potential (Celce-Murcia, 2001). The significance of students' learning styles has been the concern of many researchers. They found that students who employ or adopt one or more learning styles in a particular situation result in greater classroom success as they will be more productive in the teaching and learning process (Reid, 1987; Tubić \& Hamiloğlu, 2009). Also, students might become more involved in learning what has to be determined if we offer choices in how information or skills can be acquired (Smith \& Renzulli, 1984).

Furthermore, learning styles are indispensable for the students to maximize the individual potential and the learning process in the classroom. It often serves as a student's learning modalities, and a suitable learning style is a crucial success in learning (Rahman \& Ahmar, 2017; Sahabuddin et al., 2018). Thus, learning style is the easiest way that individuals have in absorbing, organizing, and processing information received.

Therefore, in this paper, the author aimed at identifying the students' learning styles and providing teaching strategies that may benefit the educators to enhance the effectiveness of the EFL teaching and learning process.

\section{LEARNING STYLES}

\section{A. Learning Styles in Second Language Learning}

Learning style is among the main factor that helps how and how well the students learn a second language. The term style refers to the general characteristics of an individual, the preferences that differentiate each other (Brown, 2007). In Second Language Acquisition (SLA) theory, it is stated that learning styles and cognitive styles have long been an exciting puzzle, various factors combined in the attractiveness of style concepts to SLA researchers (Doughty \& Long, 2008).

Then, Brown (2007) also claimed that the learning style has a similar meaning to cognitive style. The term cognitive style is defined as the amorphous link between personality and cognition when we learn things in general and when we attack a problem, while learning style is the amorphous link between personality and cognition in an educational context, where affective and physiological factors interacted.

Moreover, learning style also defined as a general predisposition, voluntary or not, toward processing information 
in a particular way. It means how each person captivates and recalls information and skills; nevertheless, of how that process is described, it is dramatically different each person (Dunn, 1984; Skehan, 1991). Thus, we can conclude that learning style refers to the characteristic of the individual regarding processing or understanding the knowledge given.

Expert explored that the most strongly associated dimensions of learning styles in L2 Learning were sensory preferences (Visual, Auditory, Kinaesthetic/Tactile), personality types (extroverted versus introverted; intuitiverandom versus sensing-sequential; and closure-oriented versus open-receiving), and cognitive styles (Global versus Particular; Synthesizing versus Analytic; Sharpener versus Leveler; Deductive versus Inductive; Field-Independent versus FieldDependent; Impulsive versus Reflective; and Metaphoric versus Literal) (Schmidt, 2012). Concerning this, in L2 learning, students were also different regarding brain processing (Brown, 2007).

These differences classified into two domination: leftbrain orientation and right-brain orientation, which indicated that the left and right brain also have their dominance or functions, which affected the way students learn their second language. Added to this, there was research to see what happens when the parts which connect the left and right hemisphere apart (Brown, 2007; Oflaz, 2011). The results of this study showed that there are apparent differences between the two hemispheres; the left brain is better at language skills, analytical time sequence, and skilled processing movement.

Thus, Oflaz (2011) argued that the right brain is better at copying designs, reading faces and music, discriminating of shapes, global holistic processing, understanding geometric properties, reading and expressing emotions, and understanding metaphors.

Therefore, it is deemed necessary that the students should be aware of their left and right brain orientation to explore their preference of learning and the teacher should take into account on it and help them to develop their strategies in language learning.

\section{B. Recent Studies of Learning Styles on ELT}

In second language acquisition, some studies have been carried out to identify the students' preferred learning styles. Dunn et al. (1977) found that $40 \%$ of school-age children are visual learners, that $30-40 \%$ are tactile/kinesthetic, visual/tactile, or other combinations and the remaining 20-30\% appear to be auditory learners. Then, a study conducted by Asadipiran (2016) revealed that $30 \%$ of the participants were visual learners, then the second to fifth place were tactile (25\%), auditory $(20 \%)$, individual (15\%), kinesthetic (10\%), and the less preferred one was combined learning style (5\%).

Furthermore, some researchers (Hansen and Stansfield, 1981; Day, 1984; Chapelle and Roberts, 1986; Abraham and Vann, 1987) cited in Ellis (1989) also researched on learning styles specifically on brain processing. They found that fieldindependent learners are advantaged in a formal language learning and do better in language tests that encourage a focus on form while field-dependent learners are benefited in informal language learning and do better in tests of oral communication. This research had mixed results, but in general, field-independent appears to outperform field-dependents in both formal and communicative tests.

Since the teachers need to find out the learning styles and its implication for both EFL learners and teachers in the Indonesian context, the teaching strategies are needed to enhance the students' L2 learning. Therefore, this article attempts to investigate the learning styles of EFL Learners and provide the teaching strategies for educators in the ELT classroom.

\section{Research Question}

Considering the theories of language learning and learning styles in Second Language Acquisition and English Language Teaching, this study attempts to answer the following question: a. What are the learning styles of first-semester English language education-graduate students?

b. What are the teaching strategies for educators related to students' preferred learning styles?

\section{RESEARCH METHODS}

\section{A. Respondent}

The researcher conducted a survey study. The respondents were twenty students from the first semester of the Graduateschool program majoring in English language education. Their ages ranged from 24 to 30 . The conditions as their age range and the level of proficiency were the same for all of them; they already got a minimum TOEFL score of 550 .

\section{B. Instrumentation}

The researcher used the Learning Style Survey: Assessing Your Own Learning Styles (Cohen et al., 2001). This questionnaire is one of the promising instruments for assessment learning styles since there are three aspects (Sensory Preferences, Psychological Types, and Cognitive Styles) which broken down into eleven parts (Gass \& Selinker, 2008). For each element, it consists of two until three sections; section $\mathrm{A}, \mathrm{B}$, and $\mathrm{C}$. The responses are: 'Never' equals 0 , 'Rarely' equals 1, 'Sometimes' equals 2, 'Often' equals 3, and 'Always' equals 4.

\section{Procedure}

The procedure was as follows. The author gathered the data by asking the students to fill the questionnaire. Then, the researcher distributed the survey to the selected students personally. The students are asked to fill and return it the day after the researcher distributed the questionnaire.

Then, by totaling the points based on the scores given, the overall learning preferences for each student are demonstrated. The scores interpreted by providing general descriptions of the students learning style preferences, i.e., providing a chart about each student's tendencies on learning styles for all dimensions. The respondents were utterly aware that they were participating in a research study. The researcher informed them about the 
purpose and procedures of the research in the beginning. The respondents also knew that their tests' scores would be revealed, but it would not affect their course grades.

\section{FINDINGS AND DISCUSSIONS}

\section{A. Students' Learning Styles}

By using the result of the learning style survey, the majority of preferred learning styles of each aspect was determined (Table 1). The researcher found that first-semester graduate students equally adopt all of the learning styles. The explanation was as follows.

This learning styles survey had three dimensions (sensory preferences, personality types, and cognitive styles). The first dimension is sensory preferences, which consist of one part broken down into three sections (visual, auditory, and kinesthetic). In each chapter, the maximum score is 40. From the analysis, in sensory preferences, this research concluded that all of the respondents adopted all the learning styles. The percentage showed more than $50 \%$ of the learning styles account for each of the students (75\% are visual learners, $61 \%$ are auditory learners, and $57 \%$ are kinaesthetic learners).

Then, the second dimension is personality types included three aspects (extroverted versus introverted; intuitive-random versus sensing-sequential; thinking versus feeling; and closureoriented versus open-receiving). In this dimension, each section had 24 as the maximum score. The percentage showed only Open-receiving, which had $51 \%$, then the others are more than $55 \%$, it still implied that the students employed all the personality types in any other circumstances.

TABLE I. THE PREFERRED LEARNING STYLES

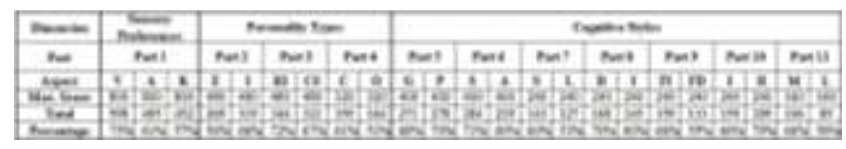

Finally, the last dimension is cognitive styles, which concern with brain processing. This dimension consisted of seven aspects, including (Global versus Particular; Synthesizing versus Analytic; Sharpener versus Leveler; Deductive versus Inductive; Field-Independent versus FieldDependent; Impulsive versus Reflective; and Metaphoric versus Literal). For part 5 and part 6, the maximum score is 20, while for part 7 to part 10 are 12, and the rest are 8 .

We can see that students varied in their brain processing, and each of the aspects inter-related, the students had more than $65 \%$ in part 5 then, the remaining styles were also more than $50 \%$. Thus, we can conclude that each of the first-year English language-graduate students had a similar preferred learning style in the three dimensions.

\section{B. Sensory Preferences}

This aspect refers to the physical, which broken down into four parts: Visual, Auditory, and Kinesthetic. After collecting and analyzing the data from students, the result was in the following figure.

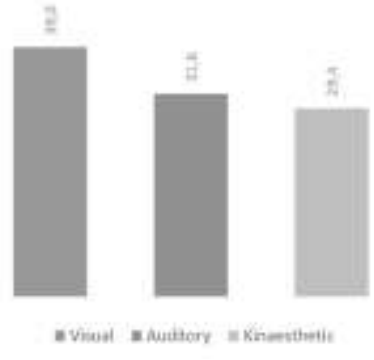

Fig. 1. Students' sensory preferences

The bar chart shows that $39 \%$ of the students were visual learners; the auditory learners were $31.6 \%$, then only $29.4 \%$ were kinaesthetic learners. We can conclude that the majority of the class are visual learners.

\section{Personality Types}

It often called psychological types, which consist of four aspects: extroverted versus introverted, intuitive-random versus sensing-sequential, thinking versus feeling, and closureoriented versus open-receiving. It was found that there is a significant relationship between this type and L2 proficiency in native-English-speaking countries of EFL (Celce-Murcia, 2001).

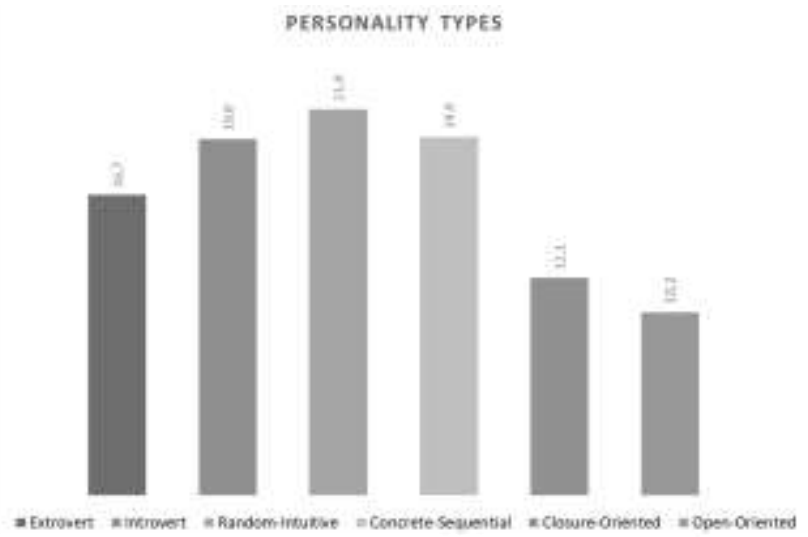

Fig. 2. Students' personality types

The figure shows that with a total of 20 respondents, most of them are random-intuitive learners, the difference is only $1.5 \%$ with concrete-sequential, then with only $0.01 \%$ slightly below the concrete-sequential, the students are more introvert than extrovert. Moreover, these first-semester students are more closure-oriented with $12.1 \%$ than open-oriented, therefore also concluded the open-oriented is the less preferred personality type.

\section{Cognitive Styles}

This dimension focuses on the main idea of the learners' preferred or habitual patterns of mental functioning (Schmidt, 2012). The aspects are: (Global versus Particular); (Synthesizing versus Analytic); (Sharpener versus Leveler); (Deductive versus Inductive); (Field-Independent versus FieldDependent); (Impulsive versus Reflective); and (Metaphoric versus Literal). 


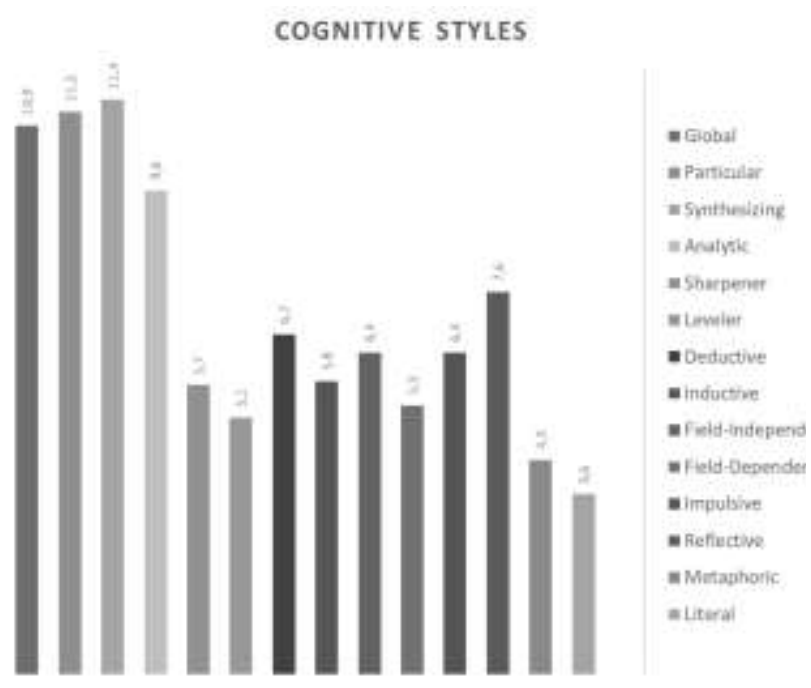

Fig. 3. Students' Cognitive Styles

From the bar chart above, it shows that synthesizing is overflowing in cognitive styles. Then, with only $0.2 \%$ slightly different, the students are precise in receiving the information. We also can see that every aspect of the cognitive style had a small difference percentage; thus, students adopted all the cognitive aspects of their learning situations.

\section{SUGGESTIONS}

The results proved that students utilized more than one learning style in each element. For example, in sensory preferences, although the majority of the respondents are visual learners, they also used auditory or kinaesthetic in particular learning situation. This finding is in line with Doughty \& Long (2008)'s theory, which stated that it is possible to employ more than one style in different learning situations.

Furthermore, in some learning situations, the students might have their style preferences and, in a different learning situation, another different set of preferences. Thus, learning styles are not dichotomous (black or white, present or absent), but generally operate on a continuum of multiple, intersecting continua (Cohen et al., 2001; Celce-Murcia, 2001). Only a few people found as having all or nothing in any of these categories. So, there are both advantages and disadvantages to every style preference.

After analyzing and getting the result of this study, the researcher suggested some teaching strategies that can cover students' preferred learning styles by adapting from this learning style survey.

\section{A. Sensory Preferences}

In designing the materials for visual learners, the teacher should consider the visual media for the students, such as pictures, videos, or charts, to make them understand the materials better. Then, for auditory learners, as they are comfortable with listening to the audio and having a lecturing session, fun listening activities will be at an advantage for these learners. Then, for kinaesthetic learners, the teacher should use realia to demonstrate the material. Added to this, since kinaesthetic learners do not like to sit for too long, the teacher can design an outdoor activity.

\section{B. Personality types}

In making the lesson plan, it should be better if the teachers divide the activities into individual and group work. Thus, for students who are introvert and extrovert, they will feel more comfortable as they do not have to stuck with such conditions that do not fit with their inner personality.

Then, in making students do the assignments/tasks, the teacher should explain the rules with step-by-step instructions then asking their understanding. If they already know what they are going to do, the teacher can wrap up the guidance then ask them to start doing it. For time management, the teacher should make sure all students understand the time limitation. For example, in one task, the students have to do the task in 20 minutes, so the teacher should remind them every 5-10 minutes before the time is up so that the students will be aware of the time limitation.

\section{Cognitive Styles}

In explaining the materials, the teacher should explain the materials from general to specific such as providing the background knowledge to make sure the students get the ideas of what they are going to learn. Then, the teacher should consider teaching the grammar and vocabulary in a context not in an isolated way, so that the students can relate to their experiences and previous knowledge on materials they learned. Since not all the students like grammar rules being taught directly, thus in teaching the grammar rules, the teacher should provide a kind of visualization in metaphorical terms.

Overall, the essential thing is that teachers should always pay attention to each of their students' characteristics, especially on how they receive the materials, how they react to classroom activities, and how they interact with others. Therefore, using an instrument to assess students' learning will be an advantage to enhance the teaching and learning process. From the suggestions above, it seems challenging for the teacher to design the materials and activities related to students' learning styles. However, if the teachers had a passion for teaching their students, it does not matter for them to be creative and innovative in designing the lesson plan or syllabus for English language materials.

\section{CONCLUSION}

Learning styles are one of the factors which affect how students learn something, especially the English language. If the students aware of their learning styles, they will be more comfortable in learning the materials and will get an excellent achievement in their learning, especially L2 learning. Added to this, good language learners need to find the learning styles which best suit them so that they will be comfortable in L2 learning (VanPatten \& Williams, 2014; Cook, 2016). 
Thus, the teacher should help students to identify their learning styles by using the learning styles survey or instrument so that the students will be aware of their learning styles. Although this learning style survey does not describe the learners' preferences all of the time and the result of any learning style questionnaire is only a general description of students' learning style preferences, at least it gave them an idea of their tendencies when they learn.

To sum up, we should remind that mismatches between teachers' and students' learning styles can result in less optimal teaching and learning processes, especially in ELT. Therefore, the teacher also the students who need to assess their styles to be aware of their preferences and possible bias.

\section{REFERENCES}

Ellis, R. (1989). Classroom learning styles and their effect on second language acquisition: A study of two learners. System, 17(2), 249-262.

Skehan, P. (1991). Individual differences in second language learning. Studies in second language acquisition, 13(2), 275-298.

Ortega, L. (2013). Understanding Second Language Acquisition. New York: Routledge.

Lightbown, P. M., Spada, N., Ranta, L., \& Rand, J. (1999). How languages are learned (Vol. 2). Oxford: Oxford university press.

Widayanti, F. D. (2013). Pentingnya Mengetahui Gaya Belajar Siswa Dalam Kegiatan Pembelajaran di Kelas. ERUDIO (Journal of Educational Innovation), 2(1).

Madya, S. (2002). Developing standards for EFL in Indonesia as part of the EFL teaching reform. TEFLIN Journal, 13(2), 142-151.

Celce-Murcia, M. (2001). Teaching English as a second or foreign language. Boston: Heinle \& Heinle.

Reid, J. M. (1987). The learning style preferences of ESL students. TESOL quarterly, 21(1), 87-111.

Tubić, T., \& Hamiloğlu, K. (2009). Linking learning styles and teaching styles. In Becoming a Teacher Educator (pp. 133-144). Springer, Dordrecht.
Smith, L. H., \& Renzulli, J. S. (1984). Learning style preferences: A practical approach for classroom teachers. Theory into practice, 23(1), 44-50.

Sahabuddin, R., Thaha, S., Nurjaya, N., \& Fatmawati, F. (2018). Effect of visual learning style and school climate on students' achievement of learning entrepreneurship at SMKN 1 Palangga. Journal of Entrepreneurship Education.

Rahman, A., \& Ahmar, A. (2017). Relationship between learning styles and learning achievement in mathematics based on genders. World Transactions on Engineering and Technology Education, 15(1).

Doughty, C. J., \& Long, M. H. (Eds.). (2008). The handbook of second language acquisition (Vol. 27). John Wiley \& Sons.

Brown, H. D. (2007). Principles of language learning and teaching. White Plains, New York: Longman.

Dunn, R. (1984). Learning style: State of the science. Theory into practice, 23(1), 10-19.

Schmidt, A. (2012). Chapter 2: Learning style preferences. Retrieved from http://www.anthonyteacher.com/wp-content/uploads/2012/03/LearningStyles-from-Cohen-Weaver.pdf

Oflaz, M. (2011). The effect of right and left brain dominance in language learning. Procedia-Social and Behavioral Sciences, 15, 1507-1513.

Dunn, R., Dunn, K., \& Price, G. E. (1977). Diagnosing learning styles: A prescription for avoiding malpractice suits. The Phi Delta Kappan, 58(5), 418420

Asadipiran, N. (2016). Identifying Young Learners' Learning Styles among Iranian EFL Learners. Theory and Practice in Language Studies, 6(7), 14441450

Cohen, A. D., Oxford, R. L., \& Chi, J. C. (2001). Learning style survey: Assessing your own learning styles. Minneapolis, MN: Center for Advanced Research on Language Acquisition. University of Minnesota. Retrieved from: http://carla.umn.edu/maxsa/documents/LearningStyleSurvey_MAXSA_IG.p

Gass, S. M. \& Selinker, L (2008). Second language acquisition: An introductory course. Routledge.

Cook, V. (2016). Second language learning and language teaching. Routledge. VanPatten, B., \& Williams, J. (Eds.). (2014). Theories in second language acquisition: An introduction. Routledge. 